\title{
PERBANDINGAN KUALITAS BETON DENGAN AGREGAT HALUS KABUPATEN MANOKWARI, KOTA SORONG DAN KABUPATEN FAKFAK
}

\author{
Lilis Fitri Handayani ${ }^{1)}$ \\ 1) Program Studi Teknik Sipil Universitas Muhammadiyah Sorong \\ Jl. Pendidikan No 27 Kota Sorong \\ Email : lilisfitrihandayani1@gmail.com
}

\begin{abstract}
ABSTRAK
Beton merupakan campuran dari agregat, bahan pengikat semen dan juga air. Dalam pembuatannya, banyak orang dapat melakukan tanpa harus memahami ilmu tentang beton. Namun dari hasil campuran tersebut tidak dapat dipastikan kualitas betonnya. Selain itu, agregat yang digunakan juga dapat mempengaruhi kualitas beton yang ada. Agar dapat memenuhi syarat dan standar kualitas beton yang sesuai, maka harus dilakukan prosedur pembuatan yang benar dan menggunakan agregat yang baik. Untuk menentukan komposisi campuran beton perlu dilakukan pengujian material yaitu kandungan lumpur dalam pasir, modulus halus butir, berat volume agregat, berat jenis agregat dan penyerapan air. Dalam pekerjaan dapat dilihat dari nilai slump yang identik dengan tingkat keplastisan beton dan nilai slump juga berpengaruh pada kuat desak beton. Selain itu quarry yang memiliki nilai karakteristik modulus kehalusan agregat halus yang paling tinggi cenderung memiliki nilai kuat tekan beton yang tinggi pula. Dari pemahaman tersebut, penulis bermaksud untuk mengkaji beberapa artikel mengenai agregat yang merupakan bahan utama pembuatan beton yaitu dengan membandingkan agregat halus (pasir) yang berasal dari quarry Sungai Maruni Kabupaten Manokwari, quarry Km. 10 Kampung Bugis Kota Sorong dan quarry di Kabupaten Fakfak yang terdiri atas quarry Kampung Seberang, quarry Kampung Sungai dan quarry Tanjung Wagom. Namun perlu dilakukan penelitian lebih lanjut dengan variasi (kombinasi) pasir dari pasir setiap quarry yang ada.
\end{abstract}

Kata Kunci : Beton, Agregat, Quarry

\section{PENDAHULUAN}

Beton merupakan campuran dari agregat, bahan pengikat semen dan juga air. Dalam pembuatannya, banyak orang dapat melakukan tanpa harus memahami ilmu tentang beton. Namun dari hasil campuran tersebut tidak dapat dipastikan kualitas betonnya. Selain itu, agregat yang digunakan juga dapat mempengaruhi kualitas beton yang ada. Agar dapat memenuhi syarat dan standar kualitas beton yang sesuai, maka harus dilakukan prosedur pembuatan yang benar dan menggunakan agregat yang baik.

Dari pemahaman di atas, penulis bermaksud untuk mengkaji beberapa artikel mengenai agregat yang merupakan bahan utama pembuatan beton yaitu dengan membandingkan agregat halus (pasir) yang berasal dari quarry Sungai Maruni Kabupaten Manokwari, quarry Km. 10 Kampung Bugis Kota Sorong dan quarry di Kabupaten Fakfak yang terdiri atas quarry Kampung Seberang, quarry Kampung Sungai dan quarry Tanjung Wagom. 


\section{METODOLOGI}

Tahapan penelitian yang digunakan adalah sebagai berikut :

1. Peninjauan lokasi quarry.

2. Persiapan material dan pengujian karakteristik agregat sesuai spesifikasi (agregat halus dan kasar).

3. Perencanaan campuran beton.

4. Pembuatan benda uji.

5. Perawatan (Curing).

6. Pengujian kuat tekan beton.

Semua metode penulisan dan analisa dalam artikel ilmiah ini merujuk pada panduan penulisan tugas akhir Fakultas Teknik Universitas Muhammadiyah Sorong tahun 2014 (Pristianto, Amri, \& Rusdi, 2014).

\section{HASIL DAN PEMBAHASAN}

Penelitian dengan tema yang sama.

Beberapa hasil penelitian terkait tema artikel ini adalah sebagai berikut :

1. Menurut Mandela, W., \& Pristianto, H. (2018) yang meneliti tentang Analisa Perbandingan Kualitas Beton Dengan Agregat Halus Quarry Sungai Maruni Manokwari Dan Kampung Bugis Sorong, didapat kesimpulan antara lain :

a. Untuk menentukan komposisi campuran beton perlu dilakukan pengujian material yaitu kandungan lumpur dalam pasir, modulus halus butir, berat volume agregat, berat jenis agregat dan penyerapan air, yang dapat dilihat pada tabel berikut :

\section{Tabel 1. Hasil Pengujian Material}

\begin{tabular}{|l|c|c|}
\hline \multicolumn{1}{|c|}{ Penelitian } & $\begin{array}{c}\text { Agregat Halus } \\
\text { (Sorong) }\end{array}$ & $\begin{array}{c}\text { Gregat Halus } \\
\text { (Manokwari) }\end{array}$ \\
\hline Kadar lumpur dalam pasir (\%) & 7,4 & 4,8 \\
\hline Modulus halus butir & 2,761 & 5,025 \\
\hline Berat isi padat (gr/cm ${ }^{3}$ ) & 1,6364 & 1,7985 \\
\hline Berat isi gembur $\left(\mathrm{gr} / \mathrm{cm}^{3}\right.$ ) & 1,4452 & 1,5883 \\
\hline Berat jenis (SSD) & 2,057 & 2,5 \\
\hline Penyerapan air (\%) & 7,991 & 0,048 \\
\hline $\begin{array}{l}\text { Ukuran agregat maksimum } \\
\text { (mm) }\end{array}$ & 40 & 40 \\
\hline
\end{tabular}

Sumber : Hasil Pengujian Laboratorium

b. Dalam pekerjaan dapat dilihat dari nilai slump yang identik dengan tingkat keplastisan beton dan nilai slump juga berpengaruh pada kuat desak beton. Adukan yang memiliki nilai slump yang rendah/kecil akan menghasilkan kuat desak yang baik.

c. Langkah perhitungan Mix Design sesuai dengan SNI diketahui dengan datadata sebagai berikut :

a) Kuat desak yang disyaratkan $f^{\prime} c=30 \mathrm{MPa}$, untuk umur 7 dan 28 hari benda uji silinder.

b) Semen yang dipakai adalah semen Portland tipe I merek tonasa $50 \mathrm{~kg}$. 
c) Tinggi slump yang disyaratkan $75-150 \mathrm{~mm}$.

d) Ukuran butiran agregat kasar $40 \mathrm{~mm}$.

e) Susunan butir agregat halus masuk dalam gradasi nomor 2 .

d. Data yang diketahui mengenai hitungan kebutuhan material per- $\mathrm{m}^{3}$ beton dengan agregat halus Sorong adalah sebagai berikut :

1) Kuat desak yang disyaratkan $f^{\prime} c=30 \mathrm{MPa}$, untuk umur 7 hari dengan benda uji silinder.

2) Nilai deviasi standar digunakan tabel1 lampiran yang didasarkan pada tingkat pengendalian mutu pekerjaan, diambil mutu pekerjaan cukup, maka $\mathrm{Sd}=5,6$ MPa. Gunakan tetapan statistic 1,64.

3) Nilai tambah, $\mathrm{M}=1,64 \times \mathrm{Sd}=1,64 \times 5,64=9,184$ digunakan $10 \mathrm{MPa}$.

4) Kuat tekan rata-rata yang ditargetkan : $f^{\prime} c r=f^{\prime} c+\mathrm{M}=30+10=40 \mathrm{MPa}$.

5) Jenis semen tipe I merk tonasa $50 \mathrm{~kg}$

6) Jenis agregat yang digunakan :

a. Agregat halus : pasir alami

b. Agregat kasar : batu pecah

7) Factor Air Semen

a. FAS maksimum ditentukan 0,6

b. Dari tabel 2 lampiran untuk agregat kasar batu pecah dan semen tipe I, kuat tekan silinder umur 7 hari f'c $=27 \mathrm{MPa}$ dengan fas $=0,5$

c. Digunakan grafik 1 lampiran hubungan antara factor air semen dan kuat tekan rata-rata sehingga didapatkan nilai fas 0,5 dengan $\mathrm{f}^{\prime} \mathrm{cr}=40 \mathrm{MPa}$.

Hasil dari data di atas dapat dilihat pada grafik tersebut :

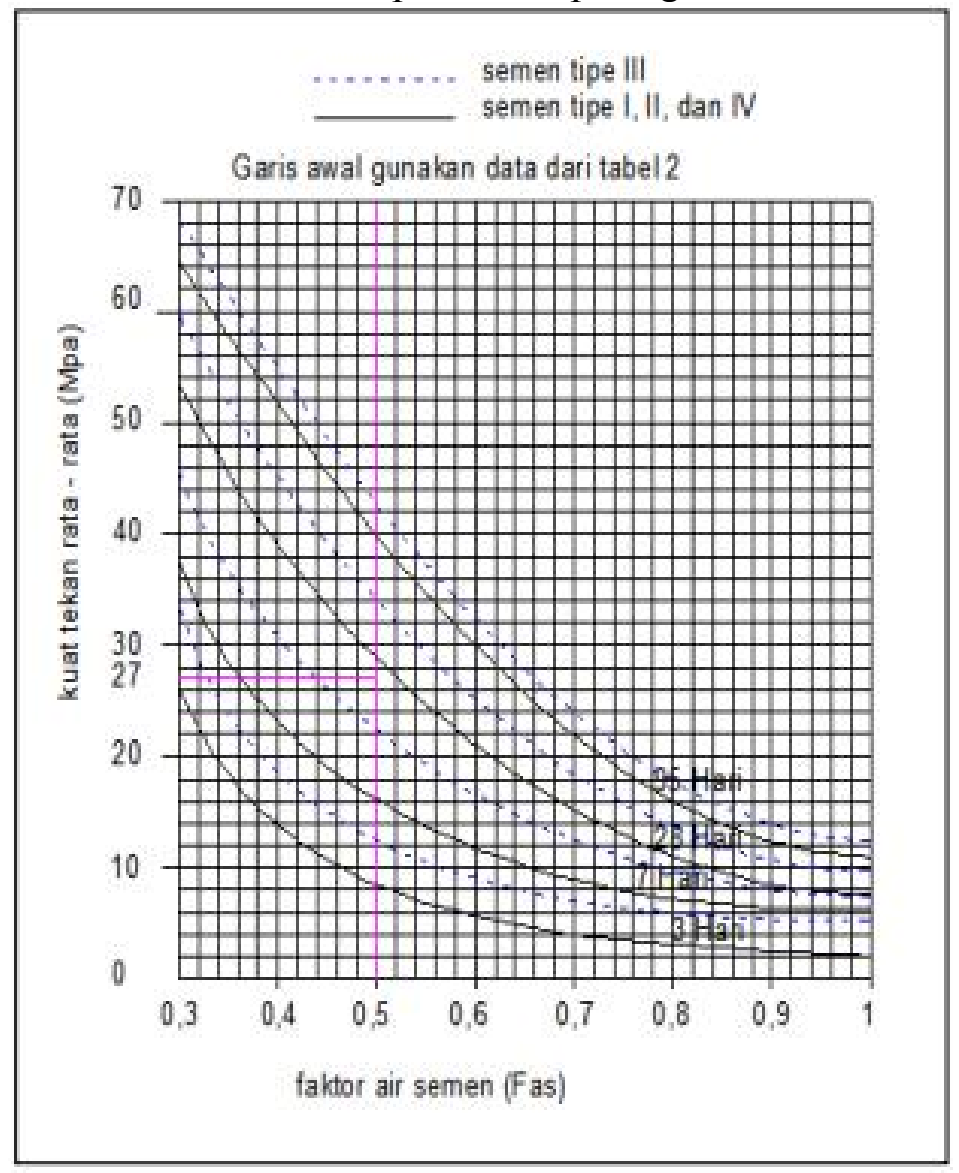


8) Factor air semen maksimum yang ditetapkan adalah 0,6 dan nilai fas yang diperoleh berdasarkan grafik 1 lampiran adalah 0,5 maka digunakan untuk perhitungan selanjutnya adalah nilai fas yang maksimum yakni 0,6 .

9) Slump ditetapkan sebesar75-150 $\mathrm{mm}$.

10) Ukuran agregat maksimum $40 \mathrm{~mm}$.

11) Kadar air bebas ditentukan dari tabel 3 lampiran,untuk nilai slump 60-180, ukuran butir maksimum $40 \mathrm{~mm}$, dan agregat yang digunakan terdiri dari agregat tak dipecah (pasir) dan agregat kasar batu pecah, yaitu :

a. Kadar air bebas untuk agregat tidak dipecah ( pasir) $175 \mathrm{~kg} / \mathrm{m}^{3}$

b. Kadar air bebas untuk agregat dipecah ( batu pecah) $205 \mathrm{~kg} / \mathrm{m}^{3}$

c. Sehingga jumlah air yang diperlukan :

$2 / 3 \times \mathrm{Wh}+1 / 3 \times \mathrm{Wk}=2 / 3 \times 175+1 / 3 \times 205=185 \mathrm{~kg} / \mathrm{m}^{3}$

12) Kadar semen $=$ jumlah air $/$ fas $=185 \mathrm{~kg} / \mathrm{m}^{3} / 0,6=308,333 \mathrm{~kg} / \mathrm{m}^{3}$

13) Kadar semen maksimum tidak ditetapkan , diabaikan.

14) Kadar semen minimum $=275 \mathrm{~kg} / \mathrm{m}^{3}$ (dalam ruang dan keadaan sekeliling nonkrososif, tabel 4 lampiran), berarti kadar semen $308,333 \mathrm{~kg} / \mathrm{m}^{3}$ sudah memenuhi.

15) Bila kadar semen hasil hitungan (12) lebih kecil dari kadar semen minimum maka digunakan kadar semen minimum, tetapi apabila hasil hitungan (12) lebih besar dari kadar semen minimum maka digunakan hasil hitungan (12). Dalam data ini digunakan hasil hitungan sebesar $=308,333 \mathrm{~kg} / \mathrm{m}^{3}$.

16) Factor air semen disesuaikan apabila kadar semen hasil hitungan (12) lebih kecil dari kadar semen minimum dalam hal ini fas harus dihitung kembali. Untuk data ini hitungan (12) lebih besar dari kadar semen minimum sehingga fas tetap 0,6 untuk hitungan selanjutnya.

17) Susunan butir agregat halus ditetapkan masuk gradasi No.2 (grafik) :

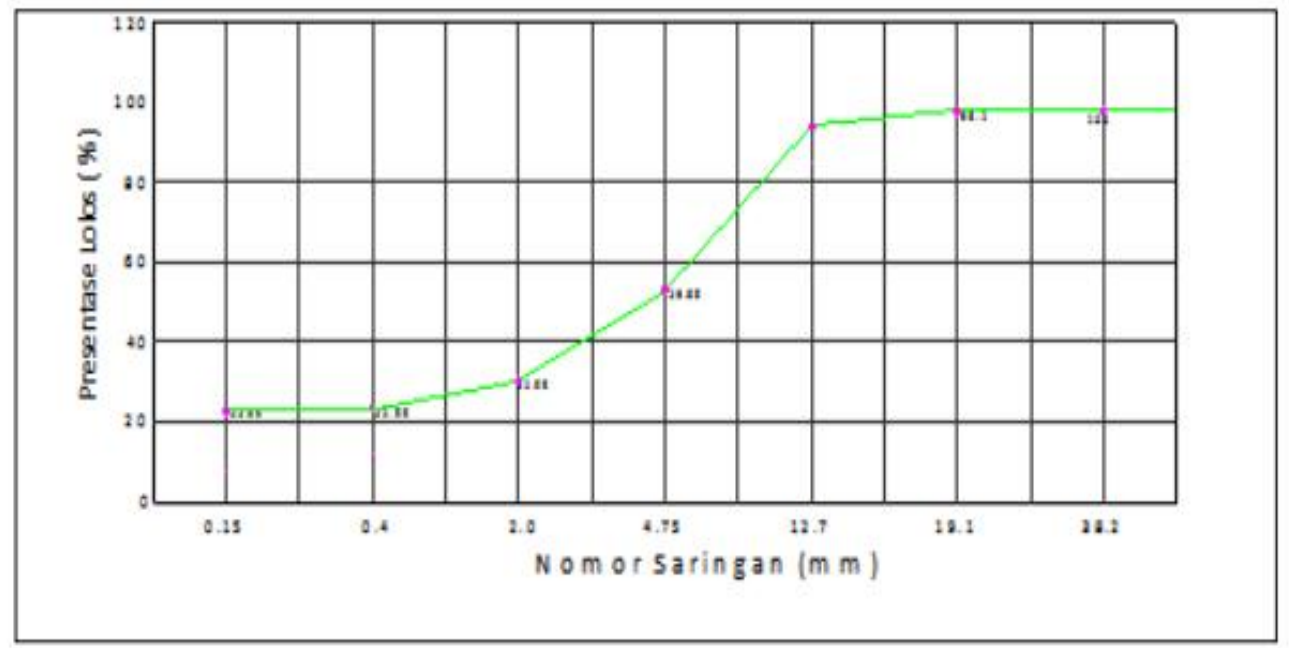

\section{Gambar 2. Grafik Gradasi Pasir}

18) Mencari persentase agregat halus (agregat yang lebih kecil dari $4.8 \mathrm{~mm}$ ). Persentase agregat halus dicari dengan grafik 14 lampiran (ukuran butir maksimum $20 \mathrm{~mm}$ ), dengan nilai slump 60-180, fas 0,6 dan susunan masuk daerah gradasi No. 2 diperoleh persentase agregat halus $43 . \%$. 
Tabel 2. Perencanaan Campuran Beton f'c $=30 \mathrm{MPa}$

\begin{tabular}{clccl}
\hline No & \multicolumn{1}{c}{ Uraian } & Nilai & Satuan & Tabel/grafik/hitungan \\
\hline 1 & Kuat tekan yang disyaratkan & 30 & $\mathrm{MPa}$ & Ditetapkan \\
2 & Deviasi standar (Sd) & 5,6 & $\mathrm{MPa}$ & Tabel llampiran \\
3 & Nilai tambah (M) & 10 & $\mathrm{MPa}$ & $1.64 \times$ Sd \\
4 & Kuat tekan ditargetkan & 40 & $\mathrm{MPa}$ & $(1)+(3)$ \\
5 & Jenis semen & Tonasa tipe I & & Ditetapkan \\
6 & Jenis agregat halus pasir alami & & & \\
7 & Factor air semen (FAS) & 0,5 & & Grafik 1 lampiran \\
8 & Factor air semen maksimum & 0,6 & & Ditetapkan \\
9 & Slump & $75-150$ & $\mathrm{~mm}$ & Ditetapkan \\
10 & Ukuran agregat maksimum & 40 & $\mathrm{~mm}$ & Ditetapkan \\
11 & Kadar air bebas & 185 & $\mathrm{Kg} / \mathrm{m}^{3}$ & Tabel 3 lampiran \\
12 & Jumlah semen & 308,33 & $\mathrm{Kg} / \mathrm{m}^{3}$ & $(11) /(7)$ \\
13 & Jumlah semen maksimum & & & Tidak ditentukan \\
14 & Jumlah semen minimum & 275 & $\mathrm{Kg} / \mathrm{m}^{3}$ & Tabel 4 lampiran \\
15 & Jumlah yang dipakai & 308,33 & $\mathrm{Kg} / \mathrm{m}^{3}$ & $(12)>(14)$ \\
\hline
\end{tabular}

Tabel 3. Perencanaan Campuran Beton f'c $=30$ MPa (lanjutan)

\begin{tabular}{llccl}
\hline No & \multicolumn{1}{c}{ Uraian } & Nilai & Satuan & Tabel/grafik/hitungan \\
\hline 16 & Factor air semen disesuaikan & 0,6 & & \\
17 & Susunan butiran agregat halus & Gradasi 2 & & Ditetapkan \\
18 & Susunan agregat kasar atau gabungan & & & Masuk zona A-B \\
19 & Persen agregat halus & 43. & $\%$ & Grafik I4 lampiran \\
20 & Berat jenis relatif agregat SSD & 2,7 & $\mathrm{Gr} / \mathrm{m}^{3}$ & Hitungan \\
21 & Berat isi beton & 2430 & $\mathrm{Kg} / \mathrm{m}^{3}$ & Grafik 16lampiran \\
22 & Kadar agregat gabungan & 2121,67 & $\mathrm{Kg} / \mathrm{m}^{3}$ & $(21)-(15)-(11)$ \\
23 & Kadar agregat halus & 912,32 & $\mathrm{Kg} / \mathrm{m}^{3}$ & $(190 \times(22)$ \\
24 & Kadar agregat kasar & 1209,35 & $\mathrm{Kg} / \mathrm{m}^{3}$ & $(22)-(23)$ \\
25 & Proporsi campuran & & & \multicolumn{2}{c}{ Agragat } \\
& Jumlah bahan & Semen & Air & Halus Kasar \\
& Tiap m ${ }^{3}$ & 308,33 & 185 & $912,32 \quad 1209,35$ \\
& Tiap campuran 5 benda uji 0,0305 & 9,40 & 5,64 & $27,83 \quad 36,89$ \\
\hline
\end{tabular}

Sumber : Hasil Pengujian Laboratorium

2. Menurut Imran, I., \& Yunus, M. (2017) yang meneliti tentang Analisis Kuat Tekan Beton yang Menggunakan Pasir Laut sebagai Agregat Halus pada Beberapa Quarry di Kabupaten Fakfak, didapat kesimpulan antara lain :

a. Untuk mengetahui kekuatan mutu beton yang akan dihasilkan dengan menggunakan agregat halus (pasir) dan agregat kasar (batu pecah) digunakan mutu beton K-250. Untuk quarry Kampung Seberang setelah dilakukan perhitungan penggabungan agregat diperoleh $40 \%$ pasir dan $60 \%$ batu pecah seperti ditunjukkan pada tabel 1 . 
Tabel 1. Hasil rancangan campuran beton sampel berasal dari quarry Kampung Seberang

\begin{tabular}{|c|c|c|c|c|}
\hline $\begin{array}{c}\text { Bahan } \\
\text { Beton }\end{array}$ & $\begin{array}{c}\text { Berat } \\
\left(\mathbf{K g} / \mathbf{m}^{3}\right)\end{array}$ & $\begin{array}{c}\text { Rasio } \\
\text { Terhadap } \\
\text { Jumlah } \\
\text { Semen } \\
(\mathbf{K g})\end{array}$ & $\begin{array}{c}\text { Berat } \\
\text { untuk 1 } \\
\text { sampel } \\
(\mathbf{K g})\end{array}$ & $\begin{array}{c}\text { Berat } \\
\text { untuk 1 } \\
\text { sampel } \\
(\mathbf{K g})\end{array}$ \\
\hline Air & 182.8883 & 0.5085 & 0.9696 & 8.7261 \\
\hline Semen & 359.6491 & 1.0000 & 1.9067 & 17.1599 \\
\hline Pasir & 556.9555 & 1.5486 & 2.9527 & 26.5740 \\
\hline $\begin{array}{c}\text { Batu } \\
\text { Pecah }\end{array}$ & 1277.5070 & 3.5521 & 6.7726 & 60.9536 \\
\hline Jumlah & $\mathbf{2 . 3 7 7 , 0 0 0}$ & & $\mathbf{1 2 . 6 0 2 0}$ & $\mathbf{1 1 3 . 4 1 4 0}$ \\
\hline
\end{tabular}

b. Untuk quarry Kampung Sungai setelah dilakukan perhitungan penggabungan agregat diperoleh $30 \%$ pasir dan $70 \%$ batu pecah seperti yang ditunjukkan pada Tabel 2. Sedangkan quarry Tanjung Wagom setelah dilakukan perhitungan penggabungan agregat diperoleh $40 \%$ pasir dan $60 \%$ batu pecah seperti yang ditunjukkan pada Tabel 3 .

Tabel 2. Hasil rancangan campuran beton sampel berasal dari quarry Kampung Sungai

\begin{tabular}{|c|c|c|c|c|}
\hline Bahan Beton & $\begin{array}{c}\text { Berat } \\
\left(\mathbf{K g} / \mathbf{m}^{3}\right)\end{array}$ & $\begin{array}{c}\text { Rasio } \\
\text { Terhadap } \\
\text { Jumlah } \\
\text { Semen }(\mathbf{K g})\end{array}$ & $\begin{array}{c}\text { Berat untuk } \\
\mathbf{1} \text { sampel } \\
(\mathbf{K g})\end{array}$ & $\begin{array}{c}\text { Berat untuk } \\
\mathbf{1} \text { sampel } \\
(\mathbf{K g})\end{array}$ \\
\hline Air & 182.8883 & 0.5085 & 0.9696 & 8.7261 \\
\hline Semen & 359.6491 & 1.0000 & 1.9067 & 17.1599 \\
\hline Pasir & 556.9555 & 1.5486 & 2.9527 & 26.5740 \\
\hline Batu Pecah & 1277.5070 & 3.5521 & 6.7726 & 60.9536 \\
\hline Jumlah & $\mathbf{2 . 3 7 7 , 0 0 0}$ & & $\mathbf{1 2 . 6 0 2 0}$ & $\mathbf{1 1 3 . 4 1 4 0}$ \\
\hline
\end{tabular}

Tabel 3. Hasil rancangan campuran beton sampel berasal dari quarry Tanjung Wagom

\begin{tabular}{|c|c|c|c|c|}
\hline Bahan Beton & $\begin{array}{c}\text { Berat } \\
\left(\mathbf{K g} / \mathbf{m}^{3}\right)\end{array}$ & $\begin{array}{c}\text { Rasio } \\
\text { Terhadap } \\
\text { Jumlah } \\
\text { Semen }(\mathbf{K g})\end{array}$ & $\begin{array}{c}\text { Berat untuk } \\
\mathbf{1} \text { sampel } \\
(\mathbf{K g})\end{array}$ & $\begin{array}{c}\text { Berat untuk } \\
\mathbf{1} \text { sampel } \\
(\mathbf{K g})\end{array}$ \\
\hline Air & 176.7036 & 0.4913 & 0.9368 & 8.4310 \\
\hline Semen & 359.6491 & 1.0000 & 1.9067 & 17.1599 \\
\hline Pasir & 764.6400 & 2.1261 & 4.0537 & 36.4832 \\
\hline Batu Pecah & 1124.0072 & 3.1253 & 5.9598 & 53.6297 \\
\hline Jumlah & $\mathbf{2 . 4 2 5 , 0 0 0}$ & & $\mathbf{1 2 . 8 5 6 0}$ & $\mathbf{1 1 5 . 7 0 4 0}$ \\
\hline
\end{tabular}


c. Setelah dilakukan perhitungan jumlah bahan selanjutnya dilakukan pencampuran bahan dan setelah itu didapatkan berat volume beton segar (basah). Untuk sampel quarry yang berasal dari Kampung Seberang, quarry Kampung Sungai, dan quarry Tanjung Wagom dapat dilihat pada Tabel 4.

Tabel 4. Berat beton segar yang dihasilkan

\begin{tabular}{|c|c|c|c|c|}
\hline $\begin{array}{c}\text { No. } \\
\text { Sampel }\end{array}$ & $\begin{array}{c}\text { Umur } \\
\text { (Hari) }\end{array}$ & $\begin{array}{c}\text { Berat } \\
\text { Sampel } \\
\text { Kampung } \\
\text { Seberang) } \\
\text { kg }\end{array}$ & $\begin{array}{c}\text { Berat } \\
\text { Sampel } \\
\text { (Quarry } \\
\text { Kampung } \\
\text { Sungai) } \\
\text { kg }\end{array}$ & $\begin{array}{c}\text { Berat } \\
\text { Sampel } \\
\text { (Quarry } \\
\text { Tanjung } \\
\text { Wagom) } \\
\text { kg }\end{array}$ \\
\hline 1 & 3 & 11.92 & 11,80 & 11,74 \\
\hline 2 & 3 & 11.78 & 11,68 & 11,64 \\
\hline 3 & 3 & 11.84 & 11,80 & 11,76 \\
\hline 4 & 3 & 11.70 & 11,84 & 11,60 \\
\hline 5 & 3 & 11.88 & 11,70 & 11,56 \\
\hline 6 & 3 & 11.88 & 11,88 & 11,74 \\
\hline 7 & 3 & 11.68 & 11,68 & 11,52 \\
\hline 8 & 3 & 11,96 & 11,96 & 11,77 \\
\hline 9 & 3 & 11,98 & 11,88 & 11,96 \\
\hline \multicolumn{2}{|c|}{ Jumlah } & $\mathbf{1 0 6 , 6 2}$ & $\mathbf{1 0 6 , 2 2}$ & $\mathbf{1 0 5 , 2 9}$ \\
\hline $\begin{array}{c}\text { Berat beton segar } \\
\text { rata-rata }\end{array}$ & $\mathbf{1 1 , 8 5}$ & $\mathbf{1 1 , 8 0}$ & $\mathbf{1 1 , 7 0}$ \\
\hline $\begin{array}{c}\text { Volume } \\
\text { benda uji }\end{array}$ & $\mathbf{0 , 0 0 5 3 0}$ & $\mathbf{0 , 0 0 5 3 0}$ & $\mathbf{0 , 0 0 5 3 0}$ \\
\hline $\begin{array}{c}\text { Berat volume } \\
\text { beton segar }\end{array}$ & $\mathbf{2 2 3 5 , 8 5}$ & $\mathbf{2 2 2 7 , 3 6}$ & $\mathbf{2 2 0 7 , 8 6}$ \\
\hline
\end{tabular}

d. Berdasarkan hasil pengujian kuat tekan pada hari ke 28 (menggunakan faktor koreksi) dengan sampel berasal dari quarry Kampung Seberang diperoleh kuat tekan rata-rata sebesar $146,58 \mathrm{~kg} / \mathrm{cm} 2$, sampel yag berasal dari quarry Kampung Sungai diperoleh kuat tekan rata-rata $165,51 \mathrm{~kg} / \mathrm{cm} 2$ dan sampel yang berasal dari quarry Tanjung Wagom diperoleh kuat tekan rata-rata $200,00 \mathrm{~kg} / \mathrm{cm} 2$.

e. Pada pengujian agregat halus yang diperoleh dari ketiga quarry semua memenuhi syarat ketentuan untuk digunakan pada campuran beton. Namun ada perbedaan pada gradasi agregat halus (pasir) pada quarry Kampung Seberang masuk pada zone 4 yang berarti pasir sangat halus, sedangkan quarry Kampung Sungai masuk pada zone 3 kategori halus, pada quarry Tanjung Wagom masuk pada zone 2 masuk kategori agak kasar. Grafik hasil pengujian gradasi butiran agregat halus untuk quarry Kampung Seberang dapat dilihat pada Gambar 1, untuk quarry Kampung Sungai pada Gambar 2, sedangkan untuk quarry Tanjung Wagom pada Gambar 3. 


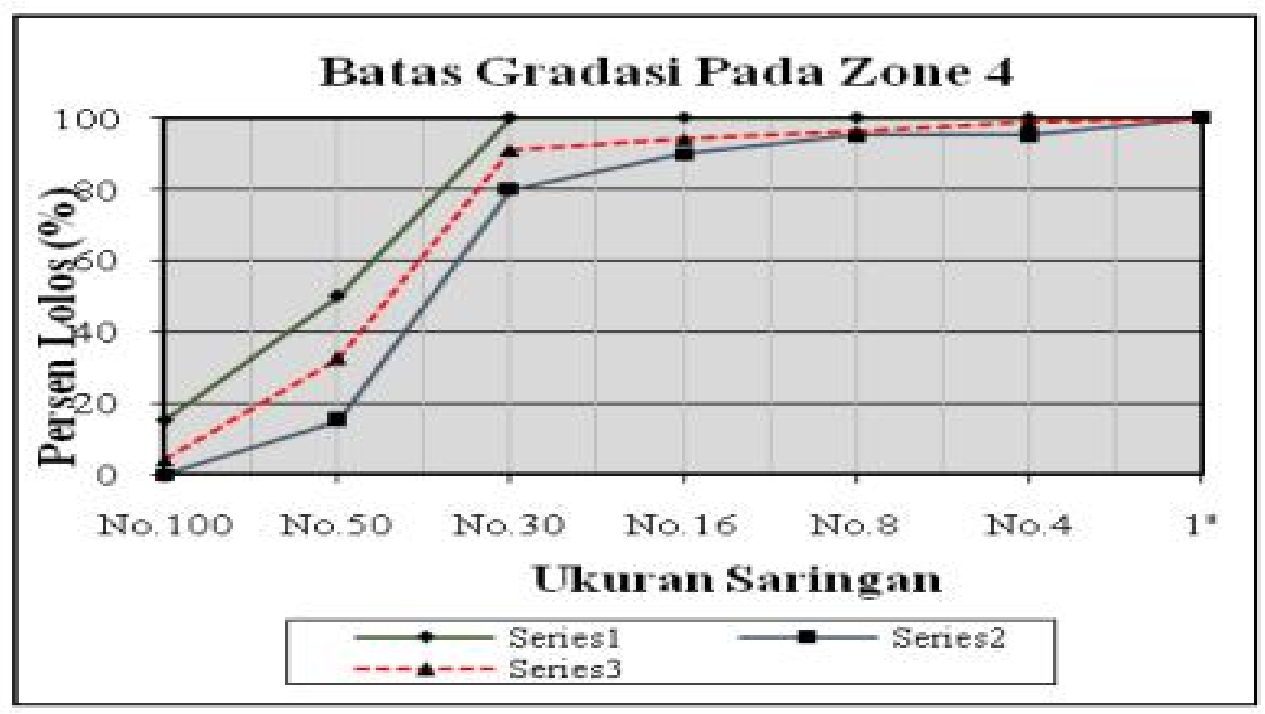

Gambar 1. Grafik Gradasi agregat halus (pasir) pada quarry Kampung Seberang

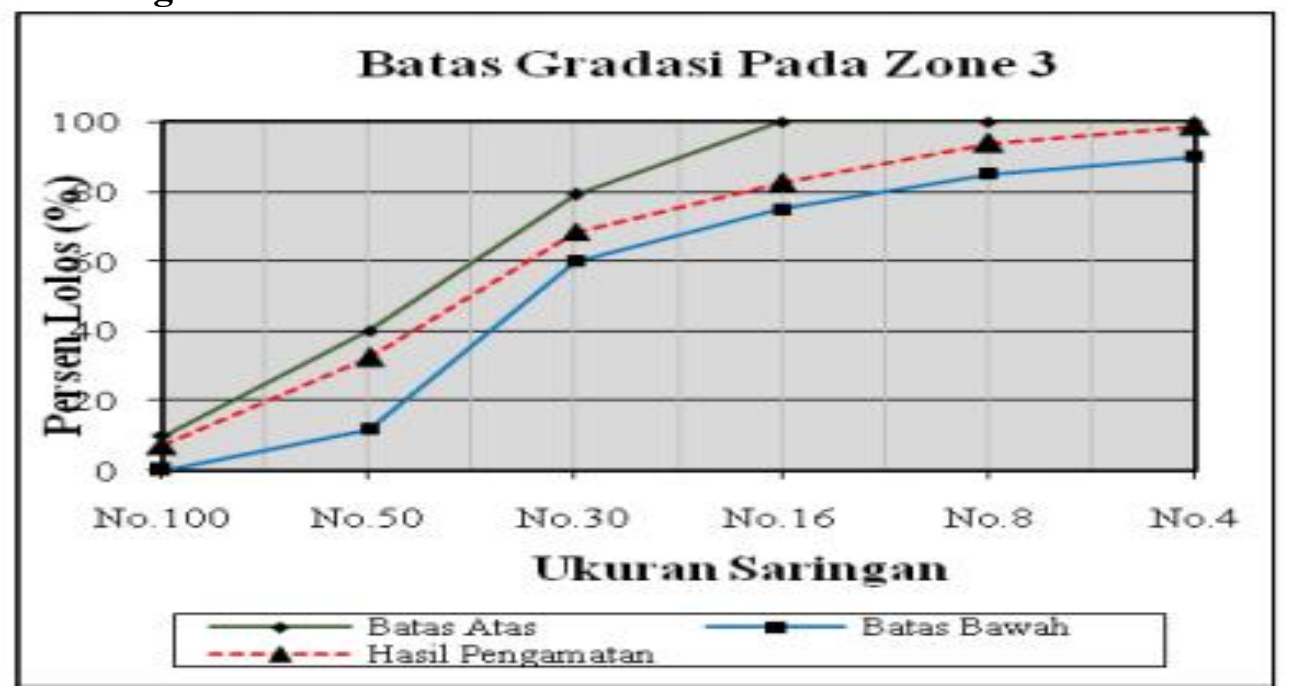

Gambar 2. Grafik Gradasi agregat halus (pasir) pada quarry Kampung Sungai

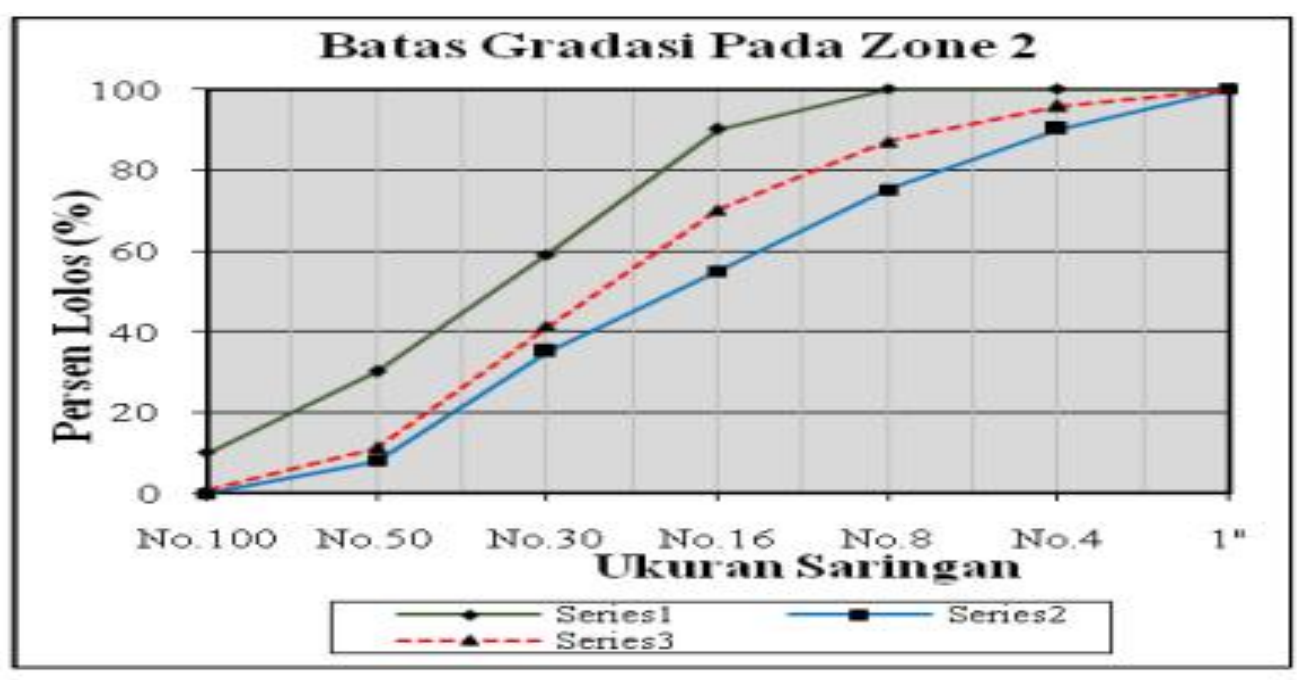

Gambar 3. Grafik Gradasi agregat halus (pasir) pada quarry Tanjung Wagom 
f. Berat volume beton segar yang dihasilkan setelah pencampuran ternyata tidak sesuai dengan mix design beton, dimana berat volume beton yang diperoleh dari hasil pencampuran lebih ringan. Hasil dari pengujian beton segar dapat dilihat pada Tabel 5.

Tabel 5. Tabel berat beton segar masing-masing quarry

\begin{tabular}{|c|c|c|c|c|}
\hline Nama Quarry & $\begin{array}{c}\text { Berat } \\
\text { Beton } \\
\text { Renc. } \\
\left(\mathbf{k g} / \mathbf{m}^{3}\right)\end{array}$ & $\begin{array}{c}\text { Berat Beton } \\
\text { Hasil } \\
\text { Pencampur } \\
\mathbf{a n} \\
\left(\mathbf{k g} / \mathbf{m}^{\mathbf{3}}\right)\end{array}$ & $\begin{array}{c}\text { Berat } \\
\text { Selisih } \\
\left(\mathbf{k g} / \mathbf{m}^{\mathbf{3}}\right)\end{array}$ & Selisih \\
\hline Kampung Seberang & 2377 & 2235 & 142 & $14.2 \%$ \\
\hline Kampung Sungai & 2377 & 2227 & 150 & $15.0 \%$ \\
\hline Tanjung Wagom & 2425 & 2207 & 218 & $21.8 \%$ \\
\hline
\end{tabular}

g. Untuk quarry Kampung Seberang, diperoleh berat volume beton setelah pencampuran sebesar $2235 \mathrm{~kg} / \mathrm{m} 3$ dengan berat selisih sebesar $142 \mathrm{~kg} / \mathrm{m} 3$ dan persentase berat selisih $14.2 \%$, hal ini disebabkan karakteristik agregat halus di quarry Kampung Seberang didominasi pasir sangat halus walaupun dari hasil pengujian karakteristik agregat halus semua parameter nilai telah memenuhi sesuai yang disyaratkan.

h. Untuk quarry Kampung Sungai, diperoleh berat volume beton setelah pencampuran sebesar $2227 \mathrm{~kg} / \mathrm{m} 3$ dengan berat selisih sebesar $150 \mathrm{~kg} / \mathrm{m} 3$ dan persentase berat selisih $15.0 \%$, hal ini disebabkan karakteristik agregat halus di quarry Kampung Seberang didominasi pasir halus walaupun dari hasil pengujian karakteristik agregat halus semua parameter nilai telah memenuhi sesuai yang disyaratkan.

i. Untuk quarry Tanjung Wagom, diperoleh berat volume beton setelah pencampuran sebesar $2207 \mathrm{~kg} / \mathrm{m} 3$ dengan berat selisih sebesar $218 \mathrm{~kg} / \mathrm{m} 3$ dan persentase berat selisih $21.8 \%$, hal ini disebabkan karakteristik agregat halus di quarry Kampung Seberang didominasi pasir agak kasar walaupun dari hasil pengujian karakteristik agregat halus semua parameter nilai telah memenuhi sesuai yang disyaratkan

j. Hasil pengujian kuat tekan beton untuk quarry Kampung Seberang diperoleh kuat tekan rata-rata $146.58 \mathrm{~kg} / \mathrm{cm} 2$ dengan kuat tekan karakteristik sebesar $122.84 \mathrm{~kg} / \mathrm{cm} 2$, untuk quarry Kampung Sungai diperoleh kuat tekan beton rata-rata $165.51 \mathrm{~kg} / \mathrm{cm} 2$ dan kuat tekan karakteristik $129.59 \mathrm{~kg} / \mathrm{cm} 2$ sedangkan untuk quarry Tanjung Wagom diperoleh kuat tekan beton rata-rata $200.00 \mathrm{~kg} / \mathrm{cm} 2$ dan kuat tekan beton karakteristik $144.27 \mathrm{~kg} / \mathrm{cm} 2$.

$\mathrm{k}$. Hal ini menunjukkan bahwa quarry yang memiliki nilai karakteristik modulus kehalusan agregat halus yang paling tinggi cenderung memiliki nilai kuat tekan beton yang tinggi. Quarry Tanjung Wagom memiliki nilai kuat tekan beton rata-rata yang paling tinggi sebesar $200.00 \mathrm{~kg} / \mathrm{cm} 2$ dan kuat tekan beton karakteristik $144.27 \mathrm{~kg} / \mathrm{cm} 2$ dengan nilai modulus kehalusan agregat halus sebesar 2.930. Quarry Kampung Sungai memiliki nilai kuat tekan beton ratarata $165.51 \mathrm{~kg} / \mathrm{cm} 2$ dan kuat tekan karakteristik $129.59 \mathrm{~kg} / \mathrm{cm} 2$ dengan nilai modulus kehalusan agregat halus sebesar 2.170 dan Quarry Kampung Seberang memiliki nilai kuat tekan beton rata-rata $146.58 \mathrm{~kg} / \mathrm{cm} 2$ dan kuat tekan karakteristik $122.84 \mathrm{~kg} / \mathrm{cm} 2$ dengan nilai modulus kehalusan agregat halus sebesar 1.836 . 


\section{KESIMPULAN}

Simpulan dari penelitian ini adalah :

1) Berdasarkan hasil penelitian yang telah dilaksanakan oleh Mandela, W., \& Pristianto, H. (2018) dapat disimpulkan bahwa :

1. Karakteristik dari agregat halus yang diuji :

a. Hasil pengujian Agregat halus quarry Sorong mengandung kandungan lumpur sebesar $7,4 \%$.

b. Hasil pengujian Agregat halus quarry Manokwari mengandung kandungan lumpur sebesar 4,8\%.

c. Dari analisa saringan yang dilaksanakan, Modulus halus butir gregat halus quarry Sorong adalah 2,761 dan Modulus halus agregat halus quarry Manokwari adalah 5,025.

2. Perbandingan kuat tekan beton :

a. Nilai kuat tekan hasil pengujian sampel beton Sorong sebagai berikut :

Umur 7 hari $=5,7607 \mathrm{MPa}$.

Umur 14 hari $=8,0355 \mathrm{MPa}$.

Umur 28 hari $=13,0153 \mathrm{MPa}$.

b. Nilai kuat tekan hasil pengujian sampel beton Manokwari sebagai berikut :

Umur 7 hari $=6,1681 \mathrm{MPa}$.

Umur 14 hari $=8,4426 \mathrm{MPa}$.

Umur 28 hari $=14,0339 \mathrm{MPa}$.

2) Berdasarkan hasil dan pembahasan penelitian yang telah dilakukan oleh Imran, I., \& Yunus, M. (2017), maka dapat ditarik kesimpulan sebagai berikut :

1. Agregat halus dari Quarry Tanjung Wagom, Quarry Kampung Seberang, Quarry Kampung Sungai dan agregat kasar dari Quarry Kayuni Secara umum dapat digunakan untuk bahan campuran beton karena memenuhi syarat karakteristik agregat beton tetapi yang paling baik agregat halus (pasir) yang paling baik adalah quarry Tanjung Wagom karena merupakan pasir yang paling baik untuk campuran beton dengan modulus kehalusan 2.93 dan masuk dalam zone 2 .

2. Kuat tekan karakteristik yang dihasilkan dari Quarry Kampung Seberang $122,84 \mathrm{~kg} / \mathrm{cm} 2$ quarry Kampung sungai $129,59 \mathrm{~kg} / \mathrm{cm} 2$ dan quarry Kampung Tanjung Wagom 144,27 kg/ cm2 dari mutu beton yang direncanakan $250 \mathrm{~kg} /$ $\mathrm{cm} 2$ atau turun 50,86\%, quarry Journal INTEK. April 2017, Volume 4 (1): 66-72 72 Kampung Sungai 48,16 \% dan quarry Tanjung Wagom turun 42,29\% atau kekuatan hanya di capai pada Quarry kmpung seberang 49,14\%, quarry Kampung Sungai 51,84\% dan quarry Tanjung Wagom turun 57,71\%. Saran dan rekomendasi penelitian sebagai berikut :

a. Perlu penelitian lebih lanjut dengan menggunakan deviasi standar yang baik dan yang dapat diterima sesuai Peraturan Beton Indonesia 1971 untuk mengetahui kuat tekan karakteristik optimal yang dapat dicapai dengan menggunakan agregat halus dan kasar dari quarry yang sama. 
b. Penelitian dapat juga dilanjutkan dengan metode trialmix mengubah faktor air semen ( W/C ) yang lebih kecil dari W/C yang digunakan pada penelitian ini.

3. Perlu dilakukan penelitian lebih lanjut dengan variasi (kombinasi) pasir dari pasir quarry Tanjung Wagom dengan Quarry Kampung Sungai kemudian variasi (kombinasi) dari ketiga quarry tersebut untuk mendapatkan pasir yang paling baik untuk campuran beton dan mendapatkan kuat tekan beton yang optimal.

\section{REFERENSI}

1. Mandela, W., \& Pristianto, H. (2018, April 22). ANALISA PERBANDINGAN KUALITAS BETON DENGAN AGREGAT HALUS QUARRY SUNGAI MARUNI MANOKWARI DAN KAMPUNG BUGIS SORONG. http://doi.org/10.17605/OSF.IO/7TA4J

2. Imran, I., \& Yunus, M. (2017). Analisis Kuat Tekan Beton yang Menggunakan Pasir Laut sebagai Agregat Halus pada Beberapa Quarry di Kabupaten Fakfak. INTEK: Jurnal Penelitian, 4(1), 66-72.

3. Pristianto, H., Amri, I., \& Rusdi, A. (2014, May 9). Pedoman Penulisan Tugas Akhir Fakultas Teknik Universitas Muhammadiyah Sorong 2014. http://doi.org/10.17605/OSF.IO/4VTJM. 